\title{
SEASONAL PROGRESSION OF AQUATIC ORGANISMS IN A TEMPORARY WETLAND IN NORTHERN CALIFORNIA
}

\author{
Michael G. Peterson ${ }^{1,3}$, Kevin B. Lunde ${ }^{2}$, Ming-Chih Chiu ${ }^{1}$, and Vincent H. Resh ${ }^{1}$
}

\begin{abstract}
Seasonal wetlands are important habitats for biodiversity of both invertebrate and vertebrate fauna. Many aquatic species have life history traits adapted to colonizing and developing in temporary aquatic habitats, and these traits influence the annual succession of the macroinvertebrate community. The chronology of taxon appearance and the variation in relative abundances during the hydroperiod are important for understanding population dynamics, trophic interactions, and responses to drought. This study investigated the successional changes in macroinvertebrate abundances in a seasonal wetland in northern California. Water quality parameters were measured regularly, including dissolved oxygen, temperature, $\mathrm{pH}$, surface area, and specific conductance during the wet season (January-July) in 2007-2009. Macroinvertebrates were collected with net sweeps (mesh $>500 \mu \mathrm{m}$ ), and the presence of life stages of amphibians were visually observed from March to June each year. As the hydroperiod progressed, wetland surface area decreased, while water temperature and specific conductance increased. Macroinvertebrate abundance increased with the progression of the hydroperiod, and the richness of macroinvertebrate predator taxa tripled from 2 families in March to 6 families in June. The earliest part of the hydroperiod in the wetland was dominated by Cyzicus clam shrimp and Linderiella occidentalis fairy shrimp. Limnephilus caddisfly larvae were few in number but were found exclusively in the early season. Sequential changes of dominant invertebrate taxa and relative abundances of macroinvertebrates were evident, particularly among several macroinvertebrate predators. Among these predators, the early-season community was dominated by larval dytiscid beetles, while later-season communities demonstrated increased predator richness (e.g., Notonecta backswimmers) and were dominated by Lestes damselflies. Larvae of the vertebrate predator Taricha torosa, which may act as a top predator, were present during the later stages of the hydroperiod. The phenology of individual aquatic taxa and their specific life history strategies may impact the sensitivity of macroinvertebrate populations to increased annual variation in hydroperiod that may result from climate changes in this region.
\end{abstract}

Resumen.- Los humedales estacionales constituyen hábitats importantes para la biodiversidad de animales invertebrados y vertebrados. Varias especies acuáticas presentan características de sus historias de vida que les permiten colonizar y desarrollarse en ambientes acuáticos temporales y dichas características influencian la sucesión anual de la comunidad de macroinvertebrados. La cronología de la aparición de los diferentes taxones y la variación en las abundancias relativas durante el periodo húmedo son factores de importancia para poder entender la dinámica poblacional, interacciones tróficas y respuestas a la sequía. Este estudio aborda los cambios sucesionales en las abundancias de macroinvertebrados en un humedal estacional en el norte de California (EUA). Parámetros indicativos de la calidad del agua fueron registrados regularmente, incluyendo oxígeno disuelto, temperatura, $\mathrm{pH}$, superficie cubierta y conductancia específica durante la temporada húmeda (Enero-Julio) entre 2007 y 2009. Los macroinvertebrados fueron recolectados usando barridos con una red (tramado $>500 \mu \mathrm{m}$ ) y se observó la presencia de distintos estados de vida de anfibios entre Marzo y Junio de cada año. A medida que el periodo húmedo continuaba, la superficie del humedal disminuyó, y en cambio tanto la temperatura como la conductancia incrementaron. La abundancia de macroinvertebrados aumentó a medida que transcurría el período húmedo y la riqueza de taxones de macroinvertebrados depredadores se triplicó de dos familias en Marzo a seis familias en Junio. Durante la primera parte del periodo húmedo, el humedal estuvo dominado por el branquiópodo Cyzicus y el anostráceo Linderiella occidentalis. A pesar de encontrar un bajo número de larvas del tricáptero Limnephilus, estas fueron halladas exclusivamente al inicio de la temporada. Los cambios secuenciales en los taxones dominantes y abundancias relativas en la comunidad de invertebrados fueron evidentes, particularmente entre varios macroinvertebrados depredadores. Entre estos últimos, la comunidad al principio de la temporada estuvo dominada por larvas de escarabajos de la familia Dysticidae, los que luego fueron desplazados para dar paso a una comunidad de depredadores más rica (e.g., Notonecta remeros), dominada por libélulas del género Lestes. Las larvas del vertebrado depredador Taricha torosa, el cual puede actuar como depredador tope, estuvieron presente durante los estados tardíos del período húmedo. La fenología de los taxones acuáticos individuales y estrategias específicas de historia de vida pueden impactar la sensibilidad de las poblaciones de macroinvertebrados frente a una variabilidad anual mayor durante el periodo húmedo, como resultado de cambios climáticos en esta región.

\footnotetext{
${ }^{1}$ Department of Environmental Science, Policy and Management, University of California, Berkeley, CA 94720-3114.

${ }^{2}$ San Francisco Bay Regional Water Quality Control Board, 1515 Clay Street, Suite 1400, Oakland, CA 94612.

3E-mail: petersmg@berkeley.edu
} 
Natural history studies contribute to our basic understanding of ecology by presenting patterns in nature in the context of biological and physical factors that may constrain or enhance species abundances (Resh and Rosenberg 2010). Studies that document the temporal co-occurrence of species in the same habitat (e.g., Poff and Matthews 1985, Berté and Pritchard 1986) or occurrences of species relative to seasonal abiotic fluctuations (Judson and Nelson 2010) can prompt hypotheses that address biotic interactions among species or document population effects of abiotic stressors. Syntheses of natural history information can inform ecological theory (McCreadie and Bedwell 2013) and are essential to mitigating impacts on threatened or endangered species. Moreover, discovery of the degree to which collective groups of species, such as guilds, have similar tolerances, traits, or habitat requirements allows for development of biological indices and other conceptual frameworks related to biological assessment (Karr 1991, Solimini et al. 2008, Lunde and Resh 2012a).

Seasonal wetlands provide aquatic habitat during certain times of year but are dry at other parts of the year. Although some organisms utilize microrefugia (Strachan et al. 2014), generally these wetlands do not support a diverse aquatic fauna when dry (Palik et al. 2001, Lunde and Resh 2012a). As water returns, macroinvertebrates access temporary wetlands via flight from nearby perennial habitat or through life history stages that survive in the sediment or nearby plants during the dry season (Batzer and Wissinger 1996, Williams 2006). During the wet season, physical and chemical factors in temporary aquatic environments, such as temperature and water chemistry, can constrain the occurrence and abundance of macroinvertebrate taxa (Williams 1996, Zamora-Muñoz and Svensson 1996). Though abiotic conditions may progress predictably across a season, high interannual variability in precipitation can lengthen or shorten the seasonal hydroperiod (Williams 1996, Boix et al. 2004, Biggs et al. 2005).

Aquatic insects have a diversity of life history strategies that enable them to utilize these temporary habitats (Williams 2006), and variability in hydroperiod length may be advantageous for some life history strategies over others (Williams 1983). For example, Ironoquia and Limnephilus caddisflies have rapid larval development, which results in early-season adult emergence, far ahead of potential pond-drying events (Williams 1983). Libellulid dragonflies, on the other hand, have slower developmental rates, and their larvae are common in the late-season pond community (Williams 1983). In years where the hydroperiod is abbreviated, taxa that require late-season development time may risk severe larval mortality.

Temporary aquatic habitats are significant sources of biodiversity in the flora and fauna of many regions (Belk and Brtek 1995, Nicolet 2004, Moss et al. 2009). In northern California, seasonal wetlands are particularly important habitat for invertebrates, such as crustaceans (e.g., fairy shrimp, tadpole shrimp; Belk and Brtek 1995, King et al. 1996), and vertebrates, such as California tiger salamanders, California red-legged frogs (Alvarez et al. 2013), and migrating birds (Gilmer et al. 1982, Isola et al. 2000). Among freshwater ecosystems, less is known about the aquatic biology of many seasonal wetlands, such as ponds, than is known about streams and lakes (Boix et al. 2012, Pérez-Bilbao et al. 2015). Moreover, wetland habitats are often vulnerable to degradation as a result of human development, including in California, where $90 \%$ of original wetlands have been filled or altered (Dahl 1990). The impact of increased temperatures and precipitation variability on hydroperiods as a result of global climate change presents concerns for the conservation of biodiversity in seasonal aquatic habitats.

We investigated seasonal variation in the abiotic conditions and phenology of aquatic macroinvertebrates, California newts, and Pacific chorus frogs in a seasonal wetland in northern California over multiple years. The objectives of this study were to (1) examine the seasonal progression of abiotic conditions during the hydroperiod of a seasonal wetland over multiple years, (2) describe seasonal variability of taxonomic composition and taxon abundances in the macroinvertebrate community, and (3) assess the succession and co-occurrence of the common aquatic macroinvertebrate and vertebrate predators.

\section{Methods}

\section{Sampling Location}

The focus of this study is a seasonal wetland known as Hog Lake (39.0316 $\mathrm{N}, 123.0789^{\circ} \mathrm{W}$ ), located at the University of California Hopland 


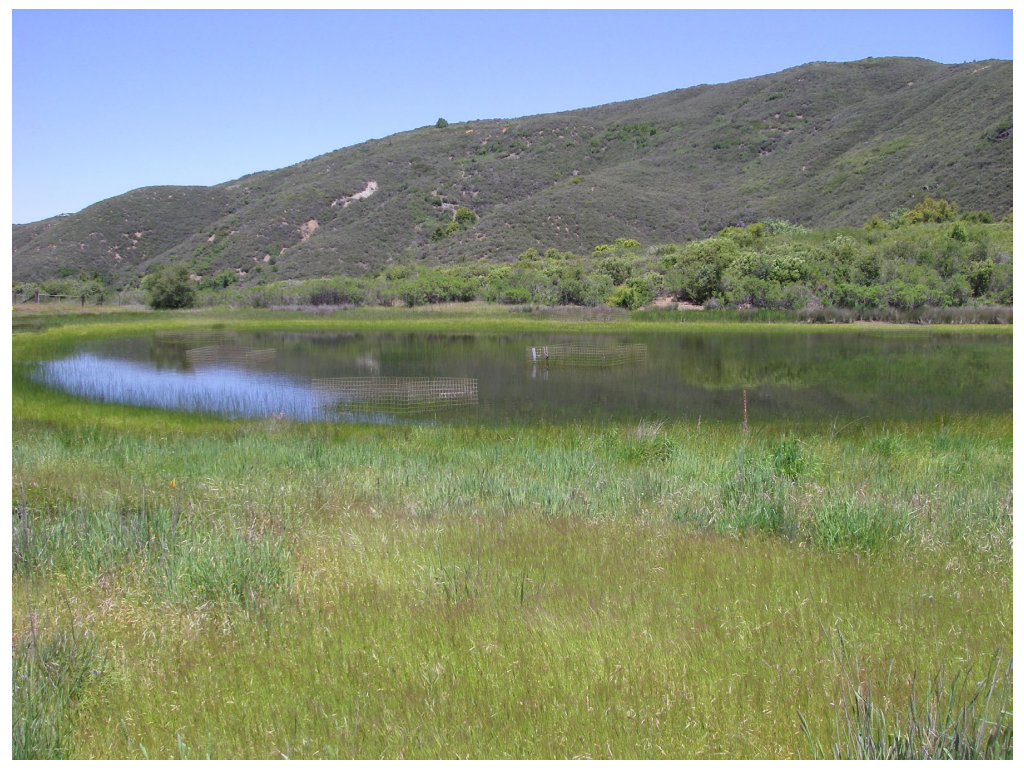

Fig. 1. The seasonal wetland Hog Lake at Hopland Research and Extension Center in northern California, USA, in May 2007.

Research and Extension Center in northern California (Mendocino County), USA. This type of small seasonal wetland $\left(3200 \mathrm{~m}^{2}\right.$; Fig. 1) is common in a Mediterranean-climate area that is characterized by hot, dry summers and mild, rainy winters. Approximately $75 \%$ of rainfall occurs during the wet months during late fall and winter (between November and February), and these storms provide the water to fill Hog Lake each year. The aquatic habitat generally remains until late June or July each summer. Although annual mean precipitation is approximately $100 \mathrm{~cm}(1952-2011)$, mean precipitation for the initial wet months of November and December (1952-2011) is $11.8 \mathrm{~cm}$ and $18.0 \mathrm{~cm}$, respectively (Hopland Research and Extension Center weather records). In contrast, mean precipitation for summer and early fall (July-October) is only $6.8 \mathrm{~cm}$ (1952-2011, Hopland Research and Extension Center). For the specific years of the study, monthly rainfall showed high variability (Fig. 2). In addition, the lake was divided into 2 halves using a rubber barrier from December 2007 to August 2008 for a separate experiment.

\section{Abiotic Measurements}

Abiotic measurements were taken every 2-4 weeks from January to June in 2007,
2008, and 2009. Physical measurements of the length, width, and circumference of the wetland were measured on a subset of sampling days with a field tape measure and were used to calculate surface area. When possible, the most current images available in Google Earth Professional were also used to determine the size of the wetland. Temperature $\left({ }^{\circ} \mathrm{C}\right)$ was measured using 2 approaches. To understand daily temperature fluctuations, a HOBO Pendant temperature logger (Onset, Bourne, MA) was placed at the bottom of Hog Lake from February through early July 2009. In addition, temperature, dissolved oxygen $\left(\mathrm{mg} \cdot \mathrm{L}^{-1}\right)$, specific conductance $(\mu \mathrm{S} \cdot$ $\mathrm{cm}^{-1}$ ), $\mathrm{pH}$, and turbidity (NTU) were measured at 2 locations (east and west ends of the wetland) in Hog Lake as part of the general abiotic sampling design (2- to 4 -week intervals). To measure dissolved oxygen, specific conductance, and temperature we used a Yellow Springs Instrument (YSI) MP 556. Turbidity was measured using a HACH $2100 \mathrm{P}$ turbidity meter, and $\mathrm{pH}$ was measured with an Oakton pHTstr 3 meter. For overall descriptions of the wetland, abiotic characteristics at the east and west sites were averaged to obtain a single value for each variable prior to analysis. 


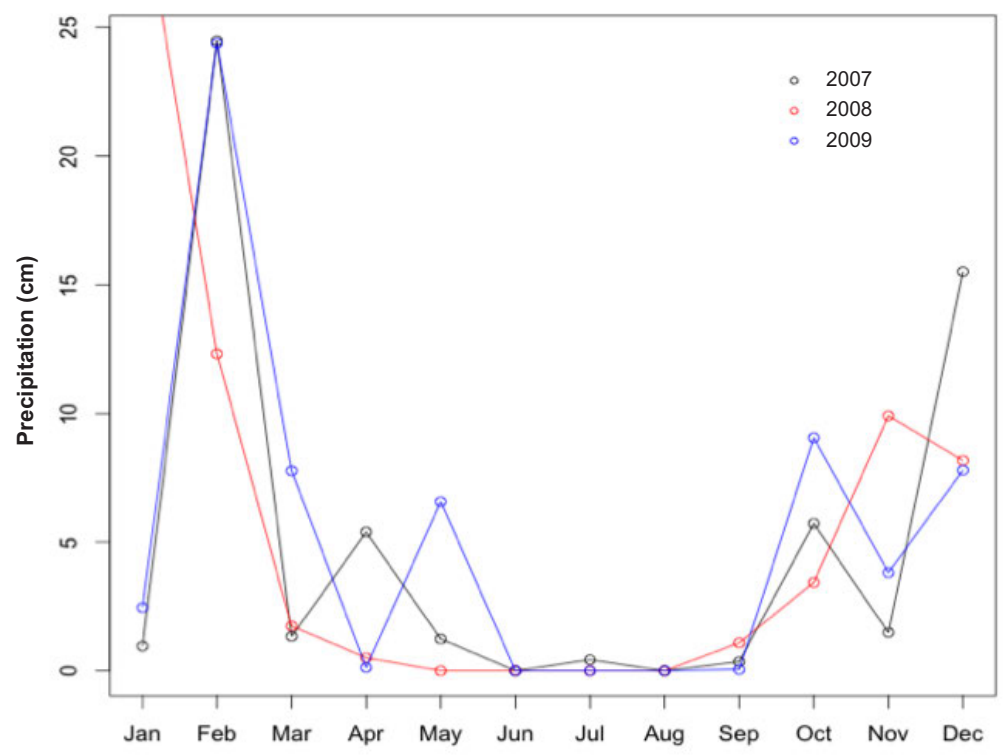

Fig. 2. Monthly precipitation (cm) at Hog Lake, Mendocino County, California, USA, during 2007, 2008, and 2009.

\section{Biological Sampling}

Aquatic macroinvertebrates were collected with a 500-um-mesh D-frame dipnet from the same 2 sites (east and west) where abiotic measurements were taken. The sampling interval was every $2-4$ weeks during the months of March, April, May, and June 2007-2009. Five net sweeps each at the east and west areas of the wetland were collected in a way that included various depths and microhabitats in the limnetic zone, thereby capturing invertebrates in the benthos and water column.

All macroinvertebrates collected were stored in $70 \%$ ethyl alcohol in the field. In the laboratory, macroinvertebrates were sorted with a $25 \times$ magnifying glass and identified to family. Some taxa were identified to genus, including Limnephilus (Trichoptera: Limnephilidae) caddisflies, Lestes (Odonata: Lestidae) damselflies, and Notonecta (Hemiptera: Notonectidae) backswimmers. Other taxa were identified to family, including dytiscid beetles and corixid water boatmen. All aquatic insects collected were identified, as well as the individuals of California fairy shrimp, Linderiella occidentalis, and the clam shrimp genus Cyzicus. Copepods were excluded because of their small sizes (they were inconsistently sampled in the $<500-\mu \mathrm{m}$-mesh D-frame net). For some samples, macroinvertebrates were subsampled and identified to family or genus by EcoAna- lysts, Inc. For subsamples, total abundance estimates were calculated by converting from the percent subsampled.

In addition to aquatic invertebrates, Hog Lake provides habitat for frogs (Lunde and Resh 2012b), newts, and migrating birds. Visual observations of all vertebrates present in the wetland and surrounding vegetation, including amphibians, garter snakes, and birds, were recorded for each sampling date. Observations of the presence or absence of life history stages, including egg, larvae, and adult, were noted for the California newt, Taricha torosa, and the Pacific chorus frog, Pseudacris regilla, during each sampling trip.

\section{Statistical Analyses}

We used nonmetric multidimensional scaling (NMS; Kruskal 1964) to assess seasonal and site differences of square-root transformed macroinvertebrate abundances (counts) in the statistical program $\mathrm{R}$, Version 3.2.1 (vegan package). Our NMS analysis (Kruskal 1964) used Sørensen (Bray-Curtis) distance to assess seasonal differences in both the abiotic factors and the aquatic invertebrate community in Hog Lake. Stress values $<0.2$ were considered significant. We used principle components analysis (PCA) to identify the abiotic factors that represented the majority of the seasonal variance and compared tested 
TABLE 1. Abiotic factors, including water temperature, lake surface area, $\mathrm{pH}$, turbidity, dissolved oxygen, calcium concentration, and specific conductance in Hog Lake samples from 2007, 2008, and 2009. Total abundance of macroinvertebrates collected at each date are also shown.

\begin{tabular}{|c|c|c|c|c|c|c|c|c|c|}
\hline Day/month & Year & $\begin{array}{c}\text { Water } \\
\text { temp. }\left({ }^{\circ} \mathrm{C}\right)\end{array}$ & $\begin{array}{c}\text { Surface } \\
\text { area }\left(\mathrm{m}^{2}\right)\end{array}$ & $\mathrm{pH}$ & $\begin{array}{l}\text { Turbidity } \\
\text { (NTU) }\end{array}$ & $\begin{array}{c}\text { Dissolved } \\
\text { oxygen } \\
\left(\mathrm{mg} \cdot \mathrm{L}^{-1}\right)\end{array}$ & $\begin{array}{c}\text { Calcium } \\
\left(\mathrm{mg} \cdot \mathrm{L}^{-1}\right)\end{array}$ & $\begin{array}{c}\text { Specific } \\
\text { conductance }\end{array}$ & $\begin{array}{c}\text { Total } \\
\text { abundance }\end{array}$ \\
\hline 11 March & 2007 & 16.8 & 3123 & 8.4 & 2.1 & 10.7 & NA & 70 & NA \\
\hline 24 March & 2007 & 20.4 & 2580 & 8.7 & 1.1 & 13.8 & NA & 109 & NA \\
\hline 15 April & 2007 & 14.6 & 2295 & 8.5 & 1.2 & 10.9 & NA & 123 & NA \\
\hline 27 May & 2007 & 24.0 & 1524 & 8.2 & NA & 6.1 & NA & 114 & 2323 \\
\hline 8 June & 2007 & 25.1 & 1160 & 8.2 & 2.5 & 8.1 & 1.8 & 126 & 3730 \\
\hline 23 June & 2007 & 22.6 & 500 & 8.4 & 2.5 & 9.0 & 1.5 & 136 & 66 \\
\hline 2 March & 2008 & 12.2 & NA & 8.9 & 4 & 8.4 & NA & 72 & 26 \\
\hline 16 March & 2008 & 9.4 & NA & 9.8 & 2.8 & 8.8 & 4 & 92 & 89 \\
\hline 20 April & 2008 & 12.8 & 1273 & 8.6 & 7.5 & 9.8 & 4 & 107 & 384 \\
\hline 18 May & 2008 & 27.1 & 900 & 8.3 & 12.9 & 6.8 & 5.1 & 144 & 233 \\
\hline 2 June & 2008 & 23.9 & 675 & 9.5 & 5.5 & 11.4 & 5.4 & 152 & 463 \\
\hline 16 June & 2008 & 28.2 & NA & 9.0 & 3.8 & 12.5 & 7.3 & 166 & 176 \\
\hline 27 June & 2008 & 26.1 & NA & NA & 8.6 & 6.8 & NA & 644 & NA \\
\hline 15 March & 2009 & 10.0 & 3200 & 8.2 & 4.5 & 7.7 & NA & 88 & NA \\
\hline 11 April & 2009 & 17.0 & NA & 7.0 & NA & 10.2 & 2 & 103 & 388 \\
\hline 25 April & 2009 & 13.7 & NA & 10.0 & NA & 9.9 & NA & 115 & 420 \\
\hline 19 May & 2009 & 27.9 & 1289 & 8.7 & 2.0 & 6.9 & 5.2 & 132 & 727 \\
\hline
\end{tabular}

linear models with those factors. Finally, we used Akaike's information criterion (AIC) scores to determine the best model fit for abiotic factors with NMS axis 1. Furthermore, we used the analysis of similarity (ANOSIM) function in the vegan $\mathrm{R}$ package with relative abundances to examine the distinctness of invertebrate communities among months.

\section{RESULTS}

\section{Abiotic Factors}

The timing and magnitude of the winter precipitation that filled Hog Lake varied each year (Fig. 2), which affected the date of both wetland filling and wetland dry down. In November and December 2006, Hog Lake received $8.8 \mathrm{~cm}$ and $15.1 \mathrm{~cm}$, respectively. In contrast, in 2007, Hog Lake received only 1.5 $\mathrm{cm}$ in November, but $15.5 \mathrm{~cm}$ in December. In 2008, Hog Lake received $9.9 \mathrm{~cm}$ and 8.2 $\mathrm{cm}$ in these months, respectively. In each case, precipitation filled the wetland to its peak by sampling dates in mid-January (2007 and 2008) or early February (2009). Total precipitation varied annually and was $58.9 \mathrm{~cm}$ for October 2006-September 2007, $68.4 \mathrm{~cm}$ for October 2007-September 2008, and 62.9 for October 2008-September 2009.

Precipitation in this area is limited from July through the end of October (Fig. 2), and Hog Lake did not fill until precipitation saturated the area in late November or December. Physical measurements in 2007, 2008, and 2009 all demonstrated that Hog Lake began holding water sometime between November and January and was dry by mid-July. The largest surface area occurred each year in January or February and steadily decreased until drying out in late June or early July (Table 1). Full capacity of the wetland corresponded to a surface area of $3200 \mathrm{~m}^{2}$, and mean surface areas for March and June were $2802 \mathrm{~m}^{2}$ and $917.5 \mathrm{~m}^{2}$, respectively.

Surface area was inversely related to water temperature each year (Table 1). Temperature ranged from $9.4{ }^{\circ} \mathrm{C}$ to $>30{ }^{\circ} \mathrm{C}$ (Fig. 3), and median temperature was nearly twice as high in May and June than in March and April. Turbidity varied widely throughout the study, ranging from 1.0 to 12.8 NTU. Specific conductance and water calcium concentrations also increased throughout the hydroperiod and were correlated $(R>0.8$; Table 1$)$.

Dissolved oxygen and $\mathrm{pH}$ were highly variable in Hog Lake, demonstrating the influence of daily and seasonal cycles in primary productivity. Dissolved oxygen ranged widely from 6.1 to $13 \mathrm{mg} \cdot \mathrm{L}^{-1}$ and showed less directionality than temperature and specific conductance (Table 1). Dissolved oxygen in Hog Lake was relatively high $\left(>10 \mathrm{mg} \cdot \mathrm{L}^{-1}\right)$ on many sampling dates. The $\mathrm{pH}$ values were alkaline, ranging from 8 to 10 . 

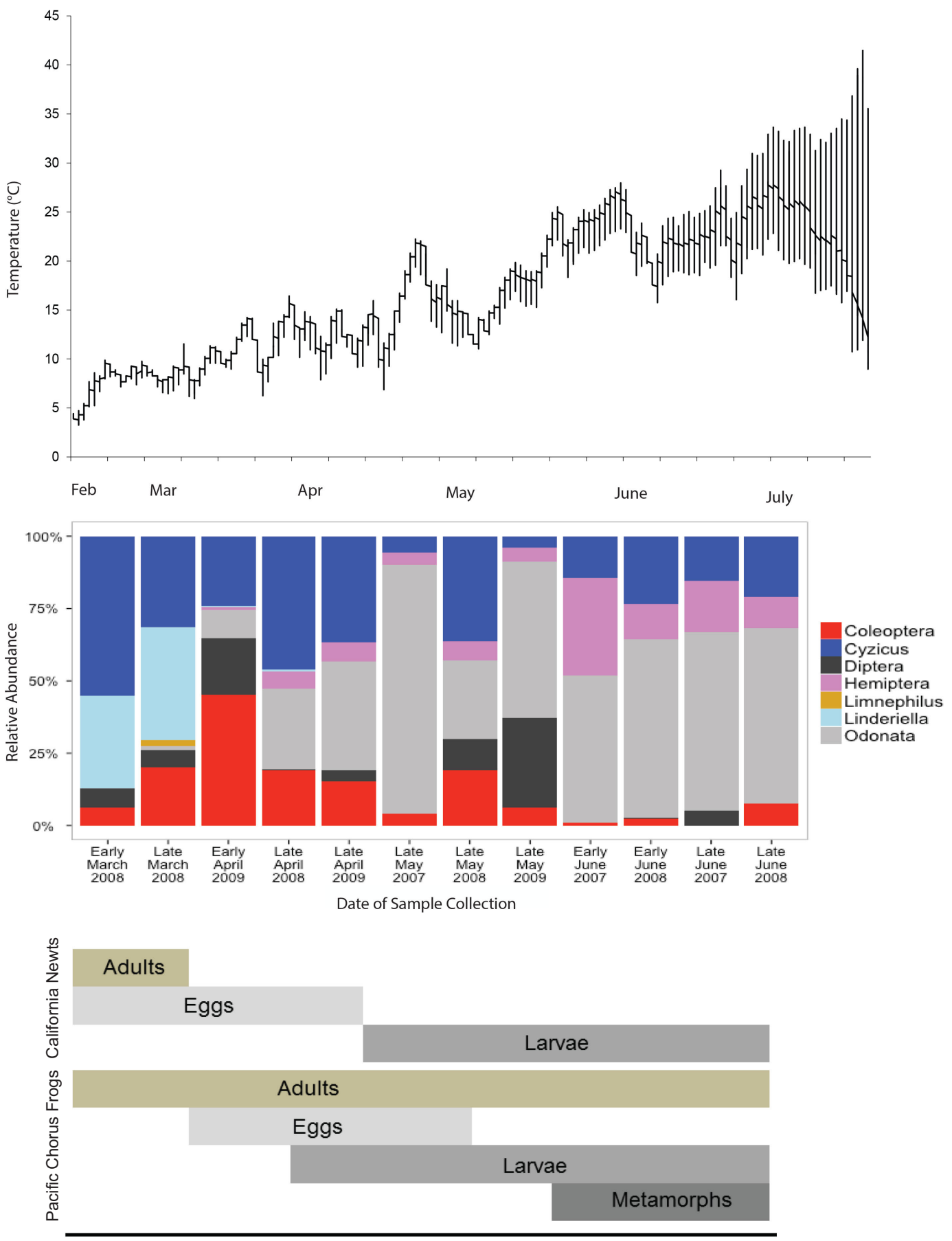

Jan Feb Early Mar Late Mar Early April Late April Early May Late May Early June Late June

Date of Observation

Fig. 3. Temperature (upper panel), macroinvertebrate relative abundance, and vertebrate life-history-stage occurrences (lower panel) for Hog Lake, California. Temperature measurements are displayed from temperature loggers set for 15-min intervals and placed in the bottom of Hog Lake during the hydroperiod of 2009. Relative abundances of macroinvertebrates (middle panel) include samples from 2007 to 2009 and exclude baetid mayflies because of their extreme peak abundances (>1000 individuals) during late season. 
TABLE 2. For each taxon, mean taxon abundances and life history strategies for surviving desiccation (Williams 2006) in samples collected by month from Hog Lake, Mendocino County, California, from the hydroperiods of 2007-2009.

\begin{tabular}{|c|c|c|c|c|c|}
\hline \multirow[b]{2}{*}{ Taxa } & \multirow[b]{2}{*}{ Life history traits } & \multicolumn{4}{|c|}{ Mean abundance } \\
\hline & & March & April & May & June \\
\hline \multicolumn{6}{|l|}{ Crustaceans } \\
\hline Linderiella occidentalis & Resistant eggs & 94.0 & 2.3 & 0.0 & 0.0 \\
\hline Cyzicus & Resistant eggs & 139.0 & 208.3 & 100.3 & 107.3 \\
\hline Trichoptera & Semiresistant eggs & & & & \\
\hline Limnephilidae Limnephilus & & 3.5 & 0.0 & 0.0 & 0.0 \\
\hline \multicolumn{6}{|l|}{ Odonata } \\
\hline Lestidae Lestes & Recolonizing adults & 2.5 & 146.0 & 127.3 & 140.0 \\
\hline Libellulidae & & 0.0 & 63.0 & 73.0 & 69.0 \\
\hline Coenagrionidae & & 0.0 & 0.0 & 227.7 & 61.0 \\
\hline Coleoptera & Resistant eggs or recolonizing adults & & & & \\
\hline Dytiscidae & & 37.0 & 151.3 & 21.7 & 3.5 \\
\hline Belostomatidae & & 0.0 & 0.0 & 0.3 & 0.0 \\
\hline Naucoridae & & 0.0 & 0.0 & 3.0 & 0.0 \\
\hline Haliplidae & & 0.0 & 0.0 & 9.3 & 1.5 \\
\hline Hydrophilidae & & 3.5 & 22.3 & 6.3 & 5.8 \\
\hline Homoptera & & 0.0 & 0.0 & 5.0 & 0.0 \\
\hline Hemiptera & Recolonizing adults & & & & \\
\hline Notonectidae Notonecta & & 0.0 & 11.3 & 16.0 & 97.5 \\
\hline Corixidae & & 0.0 & 27.3 & 14.0 & 4.8 \\
\hline Diptera & Resistant larvae & & & & \\
\hline Dixidae & & 19.0 & 21.0 & 0.0 & 0.0 \\
\hline Chironomidae & & 0.5 & 26.3 & 68.7 & 1.3 \\
\hline \multicolumn{6}{|l|}{ Ephemeroptera } \\
\hline Baetidae & & 0.0 & 0.0 & 524.0 & 793.0 \\
\hline TOTAL & & 316.5 & 679.0 & 1163.3 & 1284.5 \\
\hline
\end{tabular}

Fauna and Dynamics

A total of 17 invertebrate families and 11,318 individuals were collected and counted over the 12 sampling events of this study. Total abundance and family richness of organisms increased from March to May or June each year (Table 1). Crustaceans were more than twice as abundant as aquatic insects in March, while the opposite was generally observed in May and June (Fig. 3). Two macroinvertebrate predator taxa were present in March, while 6 macroinvertebrate predator families were present in June (Fig. 3).

Certain taxa were exclusive to early or late months in the hydroperiod. Limnephilus caddisflies were only present in one month (March 2008).The fairy shrimp Linderiella occidentalis was only present during March and early April samples (Fig. 3). Dixid flies were also exclusive to March and April samples but were less abundant than $L$. occidentalis in March. Alternatively, baetid mayflies were exclusive to May and June samples, with high abundances in June $(>3000$ individuals) and making up the majority of the macroinvertebrate abundance at that time
(Table 1). In contrast, only Cyzicus clam shrimp were present in every sample, although Lestes damselflies occurred in all samples except the earliest March sample in 2008 (Table 2).

The dominant predator taxa varied during the wet season. In March, larval dytiscid beetles were the dominant predator in Hog Lake, representing $>90 \%$ of the macroinvertebrate predators present. Although dytiscids were dominant in early April samples, representing $>80 \%$ of the macroinvertebrate predators, Lestes damselflies were also observed but in lower numbers. By late April, the relative abundance of Lestes increased relative to that of earlier samples and Lestes damselflies became the dominant macroinvertebrate predator, followed in relative abundance by dytiscids, libellulid dragonflies, corixid water boatman, and Notonecta backswimmers, respectively.

Lestes damselflies continued to be the most abundant predator through the remainder of the hydroperiod. In May, Notonecta backswimmers and libellulids were less abundant than Lestes but more abundant than all other invertebrate predators. Relatively 


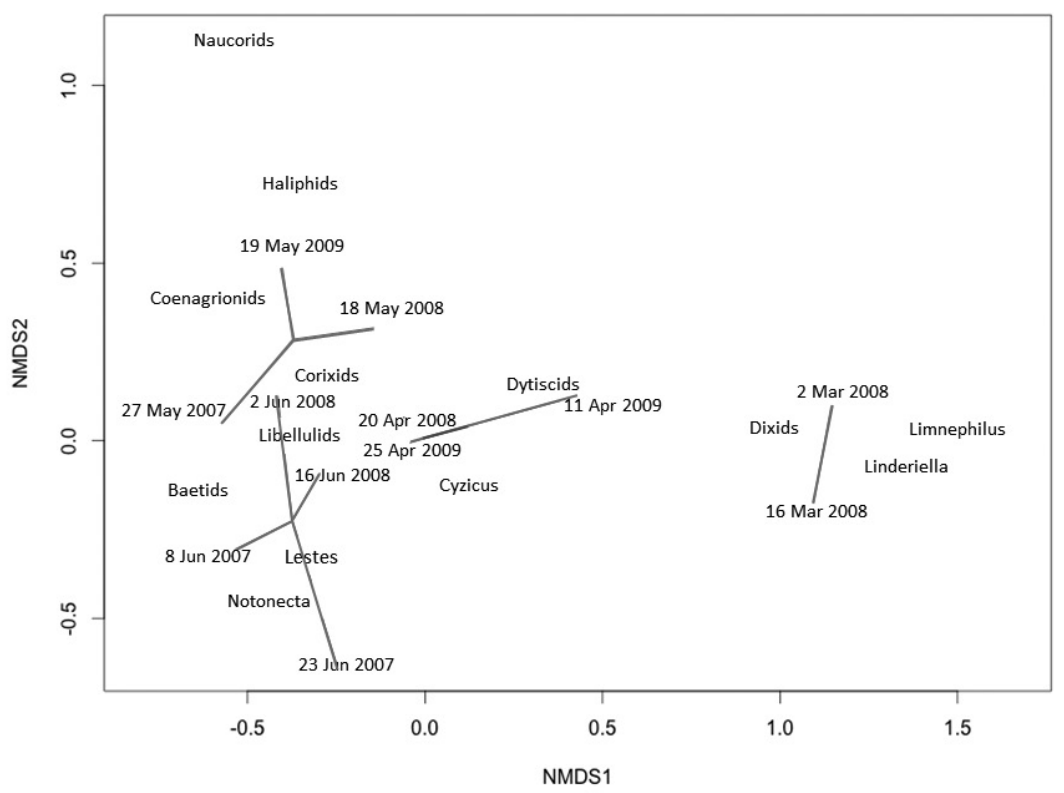

Fig. 4. Nonmetric multidimensional scaling ordination (Stress $=0.051, \mathrm{k}=2$ ) based on square-root-transformed macroinverterate abundances by sampling date and the directional influence of each taxon.

few dytiscids were found in late May. In June, Lestes remained the dominant predator, followed by Notonecta, libellulids, and dytiscids (Fig. 3).

Amphibians and reptiles were present in and around Hog Lake. Adult California newts, Taricha torosa, were observed frequently in December and January during the breeding season (Fig. 3). Eggs from the California newt were present from January through early April. Larvae were first observed in mid-April of each year, indicating emergence was occurring (Fig. 3). Newt larvae were then present at each sampling date until the wetland dried out. In addition, adult Pacific chorus frogs (Pseudacris regilla) were observed from January to May (Fig. 3). Eggs from Pacific chorus frogs were found from early to late April, larvae from late March through the end of the hydroperiod (early July), and metamorphs from mid-May through the end of the hydroperiod. Garter snakes (Thamnophis sp.) were observed on the shores of Hog Lake and numbers increased as the hydroperiod progressed in 2009. Garter snake observations ranged from 1 to 2 snakes per visit from January to early April 2009, but from 4 to 15 snakes per visit from early April to July 2009.

\section{Community Analysis}

Nonmetric multidimensional scaling of macroinvertebrate abundances indicated separation of samples by month in ordination space (Stress < 0.2; Fig. 4). Ordination distance was highly related to observed dissimilarity $\left(\mathrm{R}^{2}=\right.$ 0.982 , linear fit; $\mathrm{R}^{2}=0.995$, nonmetric fit). Moreover, samples were arranged in a progression from March to June, which is early to late spring (Fig. 4). In addition, comparisons of invertebrate communities among months using ANOSIM indicated distinct monthly communities $(R=0.417, P=0.018)$.

The separation of March samples can be strongly attributed to the presence of Limnephilus caddisflies, L. occidentalis fairy shrimp, Cyzicus clam shrimp, and members of the fly family Dixidae. May and June samples were closer in space in some years than others, and separation between samples was associated with the abundances of many taxa, including the predators Lestes, Notonecta, libellulid dragonflies, and coenagrionid dragonflies, as well as baetid mayflies, which are collectors. Although abiotic factors varied by season (Table 1), the best regression model describing the relationship between abiotic factors and NMDS axis 1 included only temperature $\left(R^{2}=0.55, P=0.006\right)$. 


\section{Discussion}

Temporal variation in abiotic conditions typically occurs in perennial wetlands (Suren and Lambert 2010) and some lakes (Reid et al. 1995). Life cycles of aquatic organisms must match suitable seasonal conditions, such as temperature or food availability. Freshwater invertebrates in seasonal wetlands must be able to avoid or withstand the environmental conditions associated with the dry season and complete their aquatic life history stages, despite interannual variability in the length and timing of hydroperiods. For those species that avoid the dry season but utilize the wet season, further challenges include synchronizing colonization and emigration to the interannual variability in the hydroperiod length.

Aquatic invertebrates have a diversity of life history strategies that allow them to use temporary habitats, including rapid larval growth and ovarian diapause (Williams 1996, Bohonak and Jenkins 2003). Moreover, oviposition of desiccation-tolerant eggs in the terrestrial environment (Jannot et al. 2008) and desiccation-tolerant early-larval stages are life history characteristics also common in seasonal wetland fauna (Batzer and Wissinger 1996). In Hog Lake, for example, crustaceans are likely characterized by eggs that can tolerate dry habitats, whereas certain aquatic insects may emerge and relocate to nearby perennial habitats as the seasonal wetland dries (e.g., Hemipterans; Macan 1939).

Fairy shrimp and other crustaceans may become established earlier in the hydroperiod because they undergo their full life cycle in temporary aquatic habitat, including as desiccation-resistant eggs during the dry season (Gallagher 1996). Although Hog Lake exists in a Mediterranean climate, the early hydroperiod taxa and life history strategies show similarity to those observed in a pond in southern Ontario, Canada (Williams 1983). The occurrence of the fairy shrimp L. occidentalis was a good descriptor for the early-hydroperiod sampling dates in Hog Lake, which is consistent with rapid early-season growth rates and short life-cycle duration also observed in Chirocephalopsis fairy shrimp relative to other invertebrates from an intermittent pond in southern Ontario (Williams 1983).

In addition to the crustacean fairy shrimp, the presence of Limnephilus caddisflies early in the successional state of Hog Lake (March 2008), when few other taxa were abundant, suggests that their larval growth occurs in the early months of the hydroperiod and that this taxon may be adapted to an early adult emergence. Occurrences of caddisfly species can vary along gradients of permanence in aquatic habitat (Wissinger et al. 2003, Wiggins 2004) and often have specific traits that reflect those habitats (Zamora-Muñoz and Svensson 1996, Wissinger et al. 1999). Limnephilus caddisflies were present early in the hydroperiod and had faster rates of development than many other aquatic insect taxa in temporary wetlands in southern Ontario (Limnephilus indivisus) and in the Rocky Mountains of Colorado (Limnephilus coloradensis, Limnephilus picturatus, and Limnephilus externus) (Williams 1983, Wissinger et al. 2003). In montane wetlands, Limnephilus caddisflies pupate in sediment (Wissinger et al. 2003), and Limnephilus in Hog Lake may employ a similar tactic. If so, that behavior would explain why we found relatively large larvae in March, but no specimens in later months. In addition, records from the Essig Museum of Entomology (University of California, Berkeley) indicate that Limnephilus nogus adults were caught in emergence traps at Hog Lake in early May, which suggests an emergence time earlier than the usual drying of the wetland in late June. Despite the fact that aquatic insects differ in evolutionary history compared with crustaceans (Will and Resh 2007) and therefore often demonstrate different life history traits that enable them to use temporary habitats, Limnephilus caddisflies, Cyzicus clam shrimp, and L. occidentalis fairy shrimp were characteristic of the earlyseason aquatic community.

The peak of larval dytiscid abundance also occurred early in the hydroperiod, in March and April, which suggests faster larval development than other aquatic insects or earlier establishment of dytiscid larvae in Hog Lake. Dytiscids are early colonizers of other seasonal wetlands (Williams 1983), which may be a result of drought- and cold-resistant eggs laid prior to wetland inundation (Nilsson and Söderström 1988), or colonization from perennial habitats (Nilsson and Svensson 1995, Schäfer et al. 2006). Additionally, high dytiscid abundances early in the hydroperiod, but not later, may suggest development and dispersal, or predation by other invertebrate (e.g., Lestes) 
or vertebrate predators (e.g., newts) present later in the hydroperiod.

Increased abundances in libellulid dragonflies, Notonecta backswimmers, and Lestes damselflies as the hydroperiod progressed may suggest different abilities to colonize and become established at Hog Lake upon completion of filling, or different developmental or physiological adaptations for using temporary habitats. Previous studies with Lestes and Notonecta showed strong dispersal abilities and aerial colonization of both permanent and seasonal wetlands (McCauley 2006, 2008, Baines et al. 2015). Life history traits also suggest that both odonates and hemipterans likely rely on recolonization of temporary habitats as adults (Macan 1939, Hinton 1954), while Limnephilus caddisflies, fairy shrimp, and clam shrimp likely utilize dessicationresistant eggs and ovarian diapause in habitat close to the temporary wetland (Bishop 1967, Daborn 1971, Wiggins 1973, Williams 2006). Dytiscid beetles may use combinations of these strategies (Nilsson and Söderström 1988, Nilsson and Svensson 1995). In addition, in the intermittent pond in Ontario studied by Williams (1983), libellulid dragonflies and Lestes damselflies demonstrated longer aquatic life-cycle duration than Limnephilus caddisflies, Chirocephalopsis fairy shrimp, or dyticid beetles, which would promote later-season habitat use.

Notonecta backswimmers and Lestes damselflies may co-occur late in the hydroperiod because they have different foraging behaviors and can therefore feed in different microhabitats. As predators, Notonecta and Lestes prey on many species of mosquitos (Blaustein et al. 1995) and microcrustacea (Havel et al. 1993), respectively. However, Notonecta has been observed to be more successful feeding in open water habitat (Blaustein et al. 1995), while Lestes was more successful in littoral habitat (Havel et al. 1993). Though we did not observe emergence events, increasing abundances of Lestes and Notonecta in May and June suggest later emergence relative to that of Limnephilus caddisflies and dytiscid beetles.

Increases in late-season predator abundance could be supported by increased prey density. For example, the surface area and estimated volume of Hog Lake decreased consistently from March to June. As habitat area decreases, organisms are concentrated, which decreases the distances between predators and prey (Boix et al. 2004, 2012). High abundance of late-season baetid mayflies likely provides an important, high-density food source for the increasing abundances of predators. The narrow temporal window of baetid occurrences in Hog Lake was also similar to that reported by Williams (1983), where baetid mayflies underwent their entire larval stage in 2-3 weeks at the end of the hydroperiod.

Late-season conditions present tradeoffs for aquatic predators. For example, smaller wetland size increases prey density, which should benefit predators (Batzer and Wissinger 1996). In Hog Lake, June samples demonstrated the highest abundance of invertebrates and the smallest wetland surface area. Late in the hydroperiod, however, predator richness also increased, which may increase predation risks for invertebrate predators. In addition, as wetlands approach dryness, predators face an increased risk of not completing their life history, which can result in catastrophic mortality for both vertebrates and invertebrates alike (e.g., Jeffries 1994).

As habitat decreased in Hog Lake, temperature increased. These conditions caused increased metabolism in poikilothermic fauna, such as the macroinvertebrates and newts examined in this study. Temperature is important for seasonal regulation of certain aquatic insect species, including odonates (Corbet 1980). Previous studies indicate that Lestes, in particular, may be adapted for the late stages of the hydroperiod. For example, damselfly development can accelerate in response to shrinking habitat (Johansson et al. 2001). Specifically, a Lestes damselfly in North Carolina had progressively higher coefficients for growth rates in each successive instar (Lutz 1968, Corbet 2003), suggesting that as temperatures warm, Lestes damselflies may be able to increase growth rate and, therefore, develop more quickly when temporary habitats become small and warm.

The presence of amphibians as top predators in seasonal wetlands can influence the composition of the macroinvertebrate community (Wissinger et al. 1999). In Hog Lake, California newts are considered top predators in this study system. The presence of eggs before mid-April, but not after, combined with the presence of larvae in mid-April, but not before, indicates that emergence of newts 
occurred in April in Hog Lake. This timing is advantageous for feeding on macroinvertebrates because both the total abundance of macroinvertebrates and the richness of macroinvertebrate families as potential prey had increased from March to April. Not only do newt larvae consume macroinvertebrates, but their chemical cues also affect macroinvertebrate behavior (Bucciarelli and Kats 2015).

The abundance of macroinvertebrates in our samples increased throughout May and June, suggesting that predation of macroinvertebrates by newts did not outpace macroinvertebrate production; however, individual taxa may have been impacted by the emergence of this predator. For example, dytiscid abundance in Hog Lake decreased concurrently with the emergence of newt larvae. Other amphibians, notably tiger salamanders in Arizona and Colorado, prey on limnephihlids and dytiscids as a minor proportion of their diet (Holomuzki and Collins 1987). Moreover, in montane wetlands, tiger salamanders preferentially prey on the most mobile or conspicuous caddisfly (Wissinger et al. 2003) and, therefore, the more mobile predators may be at heightened risk of predation. Finally, predator cues can promote aquatic insects, such as Notonecta backswimmers, to disperse at higher rates (McCauley and Rowe 2010), which could indirectly cause changes in the composition of macroinvertebrates in Hog Lake.

Variation in the annual hydroperiod of seasonal wetlands influences the macroinvertebrate community structure because aquatic organisms utilize diverse life history traits related to colonization, development, and reproduction (Jannot et al. 2008, Céréghino et al. 2012, Pérez-Bilbao et al. 2015). Certain life history strategies, such as long development time (e.g., certain trichopterans; Wiggins 1973) or low temperature needs (e.g., certain fairy shrimp) may be particularly vulnerable. Previous studies of Mediterranean-climate temporary wetlands with hydroperiods between 5 and 9 months indicate that hydroperiod length is positively related to invertebrate biodiversity (Waterkeyn et al. 2008). Hog Lake has an approximately 6-month-long hydroperiod, yet it is unknown which taxa would be vulnerable to shorter hydroperiods. Permanent wetlands can serve as source populations for some taxa to colonize seasonal wetlands and even small aquatic habitats can act as dry-season refuges for other aquatic insect taxa (Strachan et al. 2014) or short-term refuges during intermittent early-season conditions (Strachan et al. 2016). Furthermore, some life history strategies, such as slower larval metabolism during dry seasons in leptocerid caddisflies (Wickson et al. 2012), may provide advantageous flexibility for interannual variability in environmental conditions. Therefore, threats to biodiversity may be specific to certain species and also to certain life history strategies of organisms inhabiting seasonal wetlands.

Increased occurrence of drought or of warmer air temperatures as a result of climate change may impact populations of aquatic insects in seasonal wetlands. While many macroinvertebrates develop more quickly under warmer temperatures, extremes in annual variability of hydroperiod, such as during droughts, may shorten hydroperiods to the exclusion of some taxa (Sim et al. 2013). In Hog Lake, decreased early-season precipitation could delay the initial establishment of aquatic habitat, or warmer air temperature may facilitate earlier drying. Both scenarios would contribute to shorter hydroperiods and longer dry periods, which could inhibit the occurrence or abundances of certain taxa and pose a long-term threat to regional biodiversity.

\section{ACKNOWLEDGMENTS}

We thank J. Ball-Damerow and many volunteers for assistance with field collections. We are grateful to the Hopland Research and Extension Center for logistical help and longterm weather information. We acknowledge L. Hückstädt for translation of the abstract into Spanish. Additionally, we thank the Margaret C. Walker Fund for graduate research in Systematic Entomology and the Edward A. Colman Fellowship in Watershed Management from the Department of Environmental Science, Policy, and Management at the University of California, Berkeley, for support.

\section{Literature Cited}

Alvarez, J.A., D.G. Cook, J.L. Yee, M.G. van Hattem, D.R. Hong, and R.N. Fisher. 2013. Comparative microhabitat characteristics at oviposition sites of the California red-legged frog (Rana draytonii). Herpetological Conservation and Biology 8:539-551.

Baines, C.B., S.J. McCauley, and L. Rowe. 2015. Dispersal depends on body condition and predation risk 
in the semi-aquatic insect, Notonecta undulata. Ecology and Evolution 5:2307-2316.

Batzer, D.P., AND S.A. Wissinger. 1996. Ecology of insect communities in nontidal wetlands. Annual Review of Entomology 41:75-100.

Belk, D., ANd J. Brtek. 1995. Checklist of the Anostraca. Hydrobiologia 298:315-353.

Berté, S.B., and G. Pritchard. 1986. The life histories of Limnephilus externus (Hagen), Anabolia bimaculata (Walker), and Nemotaulius hostilis (Hagen) (Trichoptera, Limnephilidae) in a pond in southern Alberta, Canada. Canadian Journal of Zoology 64: $2348-2356$.

Biggs, J., P. Williams, M. Whitfield, P. Nicolet, and A. Weatherby. 2005. 15 years of pond assessment in Britain: results and lessons learned from the work of Pond Conservation. Aquatic Conservation: Marine and Freshwater Ecosystems 15:693-714.

Bishop, J.A. 1967. Some adaptations of Limnadia stanleyana King (Crustacea: Brachiopoda, Conchostraca) to a temporary freshwater environment. Journal of Animal Ecology 36:599-609.

Blaustein, L., B.P. Kotler, and D. Ward. 1995. Direct and indirect effects of a predatory backswimmer (Notonecta maculata) on community structure of desert temporary pools. Ecological Entomology 20: 311-318.

Bohonak, A.J., And D.G. Jenkins. 2003. Ecological and evolutionary significance of dispersal by freshwater invertebrates. Ecology Letters 6:783-796.

Boix, D., J. Biggs, R. Céréghino, A.P. Hull, T. KalettKa, AND B. OERTLi. 2012. Pond research and management in Europe: "Small is Beautiful." Hydrobiologia 689:1-9.

Boix, D., J. Sala, X.D. Quintana, and R. Moreno-Amich. 2004. Succession of the animal community in a Mediterranean temporary pond. Journal of the North American Benthological Society 23:29-49.

Bucciarelli, G.M., AND L.B. KaTs. 2015. Effects of newt chemical cues on the distribution and foraging behavior of stream macroinvertebrates. Hydrobiologia 749:69-81.

Céréghino, R., B. Oertli, M. Bazzanti, C. Coccia, A. Compin, J. Biggs, N. Bressi, P. Grillas, A. Hull, T. KaLETtKa, AND O. Scher. 2012. Biological traits of European pond macroinvertebrates. Hydrobiologia 689:51-61.

Conbet, P.S. 1980. Biology of Odonata. Annual Review of Entomology 25:189-217.

CORBET, P.S. 2003. A positive correlation between photoperiod and development rate in summer species of Odonata could help to make emergence date appropriate to latitude: a testable hypothesis. Journal of the Entomological Society of British Columbia 100:3-17.

DABORN, G.R. 1971. Survival and mortality of coengrionid nymphs (Odonata: Zygoptera) from the ice of an aestival pond. Canadian Journal of Zoology 49:569-571.

DAHL, T.E. 1990. Wetland losses in the United States, 1780 's to 1980 's. Report to the Congress. St. Petersberg, FL.

Gallagher, S.P. 1996. Seasonal occurrence and habit characteristics of some vernal pool branchiopoda in northern California. Journal of Crustacean Biology 16:323-329.

Gilmer, D.S., M.R. Milleer, R.D. Bauer, and J.R. Ledonne. 1982. California's Central Valley wintering waterfowl: concerns and challenges. Pages 441-452 in Kenneth Sabol, editor, Transactions of the Forty-seventh North American Wildlife and Natural Resources Conference. U.S. Fish and Wildlife, Washington, DC.

Havel, J.E., J. Link, AND J. NiedzWiecki. 1993. Selective predation by Lestes (Odonata, Lestidae) on littoral microcrustacea. Freshwater Biology 29:47-58.

Hinton, H.E. 1954. Resistance of the dry eggs of Artemia salina exposed to high tempreature. Annals of the Magazine of National History 7:158-160.

HolomuZKI, J.R., AND J.P. ColLINS. 1987. Trophic dynamics of a top predator, Ambystoma tigrinum nebulosum (Caudata: Ambystomatidae), in a lentic community. Copeia 1987:949-957.

Isola, C.R., M.A. Colwell, O.W. TaFt, and R.J. Safran. 2000. Interspecific differences in habitat use of shorebirds and waterfowl foraging in managed wetlands of California's San Joaquin Valley. Waterbirds 23:196-203.

Jannot, J.E., S.A. Wissinger, And J.R. Lucas. 2008. Diet and a developmental time constraint alter life-history trade-offs in a caddisfly (Trichoptera: Limnephilidae). Biological Journal of the Linnean Society 95:495-504.

JefFries, M. 1994. Invertebrate communities and turnover in wetland ponds affected by drought. Freshwater Biology 32:603-612.

Johansson, F., R. Stoks, L. Rowe, and M. De Block. 2001. Life history plasticity in a damselfly: effects of combined time and biotic constraints. Ecology 82:1857-1869.

Judson, S.W., AND C.R. Nelson. 2010. Diversity, phenology, and elevational distribution of Ephemeroptera, Plecoptera, and Trichoptera in American Fork Canyon, Utah. Western North American Naturalist $70: 526-540$

KARR, J.R. 1991. Biological integrity: a long-neglected aspect of water resource management. Ecological Applications 1:66-84.

King, J.L., M.A. Simovich, and R.C. Brusca. 1996. Species richness, endemism and ecology of crustacean assemblages in northern California vernal pools. Hydrobiologia 328:85-116.

Kruskal, J.B. 1964. Multidimensional scaling by optimizing goodness of fit to a nonmetric hypothesis. Psychometrika 29:1-27.

Lunde, K.B., AND V.H. Resh. 2012a. Development and validation of a macroinvertebrate index of biotic integrity (IBI) for assessing urban impacts to Northern California freshwater wetlands. Environmental Monitoring and Assessment 184:3653-3674.

LUNDE, K.B., AND V.H. RESH. 2012b. Using an ecosystemlevel manipulation to understand host-parasite interactions and how they vary with study venue. Ecosphere 3:1-18.

LuTZ, E. 1968. Effects of temperature and photoperiod on larval development in Lestes eurinus (Odonata: Lestidae). Ecology 49:637-644.

MACAN, T.T. 1939. Notes on the migration of some aquatic insects. Journal of the Society for British Entomology 2:1-6.

McCauley, S.J. 2006. The effects of dispersal and recruitment limitation on community structure of odonates in artificial ponds. Ecography 29:585-595.

McCauley, S.J. 2008. Slow, fast and in between: habitat distribution and behaviour of larvae in nine species 
of libellulid dragonfly. Freshwater Biology 53: 253-263.

McCauley, S.J., And L. Rowe. 2010. Notonecta exhibit threat-sensitive, predator-induced dispersal. Biology Letters 6:449-452.

McCreadie, J.W., and C.R. Bedwell. 2013. Patterns of co-occurrence of stream insects and an examination of a causal mechanism: ecological checkerboard or habitat checkerboard? Insect Conservation and Diversity 6:105-113.

Moss, B., D. Hering, A.J. Green, A. Aidoud, E. Becares, M. Beklioglu, H. Bennion, D. Boix, S. Brucet, and L. Carvalho, ET AL. 2009. Climate change and the future of freshwater biodiversity in Europe: a primer for policy-makers. Freshwater Reviews 2:103-130.

Nicolet, P. 2004. The wetland plant and macroinvertebrate assemblages of temporary ponds in England and Wales. Biological Conservation 120:261-278.

Nilsson, A.N., AND O. SÖDERSTRÖM. 1988. Larval consumption rates, interspecific predation, and local guild composition of egg-overwintering Agabus (Coleoptera, Dytiscidae) species in vernal ponds. Oecologia 76:131-137.

Nilsson, A.N., AND B.W. Svensson. 1995. Assemblages of dytiscid predators and culicid prey in relation to environmental factors in natural and clear-cut boreal swamp forest pools. Hydrobiologia 308:183-196.

Palik, B., D.P. Batzer, R. Buech, D. Nichols, K. Cease, L. Egeland, and D.E. Streblow. 2001. Seasonal pond characteristics across a chronosequence of adjacent forest ages in northern Minnesota, USA. Wetlands 21:532-542.

Pérez-Bilbao, A., C.J. Benetti, and J. Garrido. 2015. Assessment of the effects of the dry period on the faunal composition of aquatic macroinvertebrate assemblages in two temporary ponds in NW Spain. Journal of Limnology 74:467-476.

Poff, N.L., AND R.A. MatThews. 1985. The replacement of Stenonema spp. by Caenis diminuta Walker as the numerical dominant in the mayfly assemblage of a thermally-stressed stream. Journal of Freshwater Ecology 3:19-26.

ReID, R.A., K.M. Somers, AND S.M. David. 1995. Spatial and temporal variation in littoral-zone benthic invertebrates from three south-central Ontario lakes. Canadian Journal of Fisheries and Aquatic Sciences 52:1406-1420.

Resh, V.R., and D. Rosenberg. 2010. Recent trends in life history research on benthic macroinvertebrates. Journal of the North American Benthological Society 29:207-219.

Schäfer, M.L., E. Lundkvist, J. Landin, T.Z. Persson, AND J.O. LUNDSTRÖM. 2006. Influence of landscape structure on mosquitoes (Diptera: Culicidae) and dytiscids (Coleoptera: Dytiscidae) at five spatial scales in Swedish wetlands. Wetlands 26:57-68.

Sim, L.L., J.A. Davis, K. Strehlow, M. McGuire, K.M. Trayler, S. Wild, P.J. Papas, and J. O’Connor. 2013. The influence of changing hydroregime on the invertebrate communities of temporary seasonal wetlands. Freshwater Science 32:327-342.

Solimini, A.G., M. Bazzanti, A. Ruggiero, and G. CarCHINI. 2008. Developing a multimetric index of eco- logical integrity based on macroinvertebrates of mountain ponds in central Italy. Hydrobiologia 597:109-123.

Strachan, S.R., E.T. Chester, and B.J. Robson. 2014. Microrefuges from drying for invertebrates in a seasonal wetland. Freshwater Biology 59:2528-2538.

Strachan, S.R., E.T. Chester, and B.J. Robson. 2016. Habitat alters the effect of false starts on seasonalwetland invertebrates. Freshwater Biology 61: 680-692.

Suren, A., AND P. LAmbert. 2010. Temporal variation of invertebrate communities in perennial wetlands. New Zealand Journal of Marine and Freshwater Research 44:229-246.

Waterkeyn, A., P. Grillas, B. Vanschoenwinkel, and L. BRENDONCK. 2008. Invertebrate community patterns in Mediterranean temporary wetlands along hydroperiod and salinity gradients. Freshwater Biology 53:1808-1822.

Wickson, S., E.T. Chester, and B.J. Robson. 2012. Aestivation provides flexible mechanisms for survival of stream drying in a larval trichopteran. Marine and Freshwater Research 63:821-826.

WigGINS, G.B. 1973. Contribution to the biology of caddisflies (Trichoptera) in temporary pools. Life Sciences Contributions of the Royal Ontario Museum 88:1-28.

Wiggins, G.B. 2004. Caddisflies: the underwater architects. University of Toronto Press, Toronto, Ontario, Canada.

WILL, K., AND V.H. REsh. 2007. Phylogenetic relationhips and evolutionary adaptations of aquatic insects. Pages 139-156 in W. Merritt, K.W. Cummins, and M. Berg, editors, An introduction to the aquatic insects of North America. 4th edition. Kendall/Hunt Publishing Company, Dubuque, IA.

Williams, D. 2006. The biology of temporary waters. Oxford University Press, New York, NY.

Williams, D.D. 1983. The natural-history of a nearctic temporary pond in Ontario with remarks on continental variation in such habitats. Internationale Revue Der Gesamten Hydrobiologie 68:239-253.

WiLliams, D.D. 1996. Environmental constraints in temporary fresh waters and their consequences for the insect fauna. Journal of the North American Benthological Society 15:634-650.

Wissinger, S.A., W.S. Brown, and J.E. Jannot. 2003. Caddisfly life histories along permanence gradients in high-altitude wetlands in Colorado (U.S.A.). Freshwater Biology 48:255-270.

Wissinger, S.A., H.H. Whiteman, G.B. Sparks, G.L. Rouse, and W.S. BRown. 1999. Foraging trade-offs along a predator-permanence gradient in subalpine wetlands. Ecology 80:2102-2116.

Zamora-Muñoz, C., And B.W. Svensson. 1996. Survival of caddis larvae in relation to their case material in a group of temporary and permanent pools. Freshwater Biology 36:23-31.

Received 30 August 2016

Accepted 14 February 2017

Published online 30 June 2017 